\title{
Anti-NMDAR encephalitis \\ Demonstration of neuroinflammation and the effect of immunotherapy
}

\section{Figure $\quad\left[{ }^{123} \mid\right] C L I N D E-S P E C T$ and coregistered MRI in a patient with anti-NMDA receptor encephalitis}

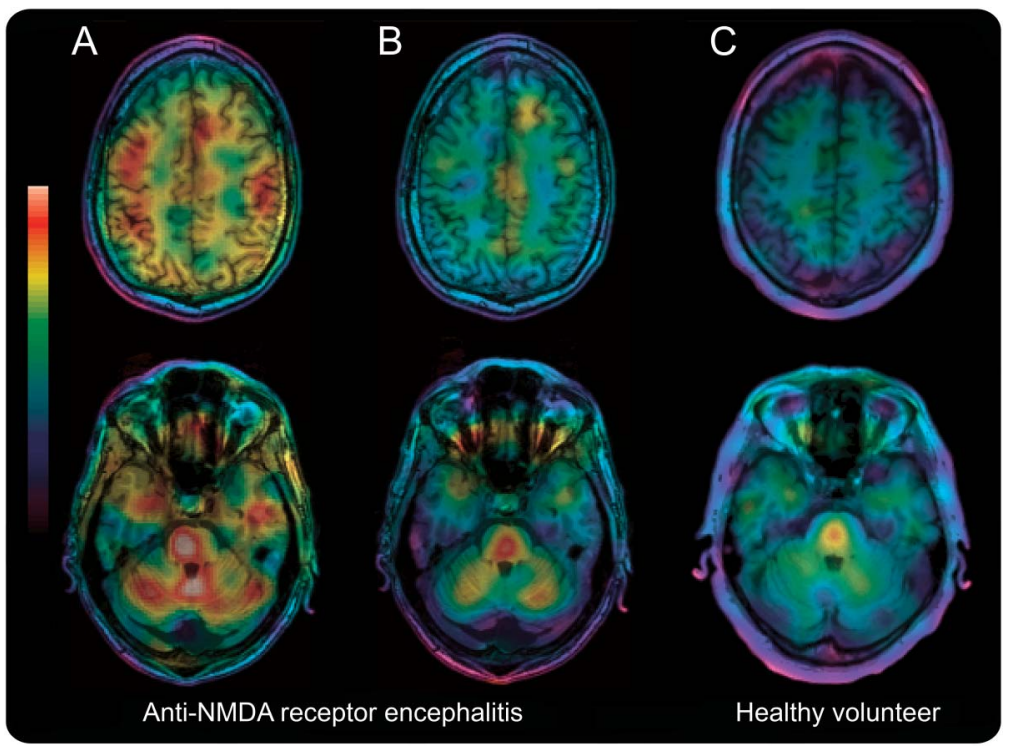

At the start of immunotherapy, (A) [123]]CLINDE-binding to TSPO was strongly increased (neocortical distribution volume $\left.\left[V_{T}\right]=6.3 \mathrm{~mL} / \mathrm{cm}^{3}\right)$, but almost normalized $\left(V_{T}=4.0 \mathrm{~mL} / \mathrm{cm}^{3}\right)$ after 7 weeks of immunotherapy $(B)$ compared to a healthy volunteer $(C)\left(V_{T}=3.0 \mathrm{~mL} / \mathrm{cm}^{3}\right)$.

A 35-year-old man presented with perceptual difficulties and delusions. At presentation, there were orofacial dyskinesias, catatonia, and autonomic instability. Anti-NMDA receptor (NMDAR) antibodies were detected in CSF. ${ }^{1}$ Cerebral MRI was unremarkable. At the start of immunotherapy (methylprednisolone and plasmapheresis), [123I]CLINDE-SPECT demonstrated a strongly increased binding to TSPO in cortical and subcortical brain regions similar to the distribution of NMDAR in the brain and different from FDG-PET changes reported in the literature (figure, A). TSPO is present on activated microglia and used as a measure of regional neuroinflammation. ${ }^{2}$ After 7 weeks of immunotherapy (figure, B), TSPO binding was close to normal values (figure, C) and the patient was back to work part time as a computer scientist despite mild cognitive problems.

Per Jensen, MD, Daniel Kondziella, MD, PhD, Gerda Thomsen, BS, Agnete Dyssegaard, MS, Claus Svarer, PhD, Lars H. Pinborg, $M D, P h D$

From Department of Neurology, Rigshospitalet, København, Denmark.

Author contributions: Per Jensen: acquired and analyzed the data. Daniel Kondziella, Gerda Thomsen, and Agnete Dyssegaard: acquired data and revised the manuscript. Claus Svarer: prepared the figure, analyzed data, and revised the manuscript. Lars H. Pinborg: designed the concept, analyzed data, and wrote the clinical summary.

Study funding: Supported by the European Union's Seventh Framework Programme (FP7/2007-2013) under grant agreement HEALTH-F2-2011-278850 (INMiND) and the Danish Research Agency.

Disclosure: The authors report no disclosures relevant to the manuscript. Go to Neurology.org for full disclosures.

Correspondence to Dr. Pinborg: lars.pinborg@nru.dk

1. Dalmau J, Lancaster E, Martinez-Hernandez E, Rosenfeld MR, Balice-Gordon R. Clinical experience and laboratory investigations in patients with anti-NMDAR encephalitis. Lancet Neurol 2011;10:63-74.

2. Jacobs AH, Tavitian B. Noninvasive molecular imaging of neuroinflammation. J Cereb Blood Flow Metab 2012;32:1393-1415. 


\section{Neurology}

\section{Anti-NMDAR encephalitis: Demonstration of neuroinflammation and the effect of immunotherapy}

Per Jensen, Daniel Kondziella, Gerda Thomsen, et al. Neurology 2015;84;859

DOI 10.1212/WNL.0000000000001278

This information is current as of February 23, 2015

\section{Updated Information \&} Services

References

Subspecialty Collections

\section{Permissions \& Licensing}

Reprints including high resolution figures, can be found at: http://n.neurology.org/content/84/8/859.full

This article cites 2 articles, 0 of which you can access for free at: http://n.neurology.org/content/84/8/859.full\#ref-list-1

This article, along with others on similar topics, appears in the following collection(s):

Autoimmune diseases

http://n.neurology.org/cgi/collection/autoimmune_diseases

Encephalitis

http://n.neurology.org/cgi/collection/encephalitis

MRI

http://n.neurology.org/cgi/collection/mri

PET

http://n.neurology.org/cgi/collection/pet

SPECT

http://n.neurology.org/cgi/collection/spect

Information about reproducing this article in parts (figures,tables) or in its entirety can be found online at:

http://www.neurology.org/about/about_the_journal\#permissions

Information about ordering reprints can be found online: http://n.neurology.org/subscribers/advertise

Neurology ${ }^{\circledR}$ is the official journal of the American Academy of Neurology. Published continuously since 1951, it is now a weekly with 48 issues per year. Copyright (C 2015 American Academy of Neurology. All rights reserved. Print ISSN: 0028-3878. Online ISSN: 1526-632X.

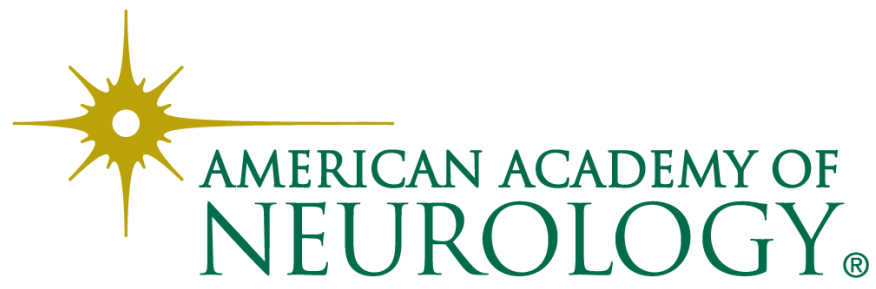

